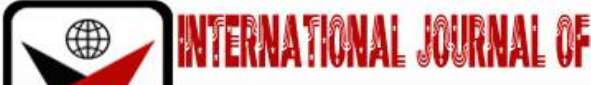

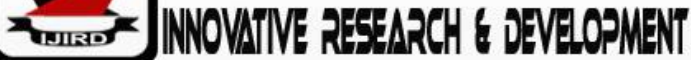

ISSN 2278-0211 (Online)

\section{Ghanaian Senior High School Students' Perception on the School Counsellor's Role: the Case of Three Public Senior High Schools in the Offinso Municipality}

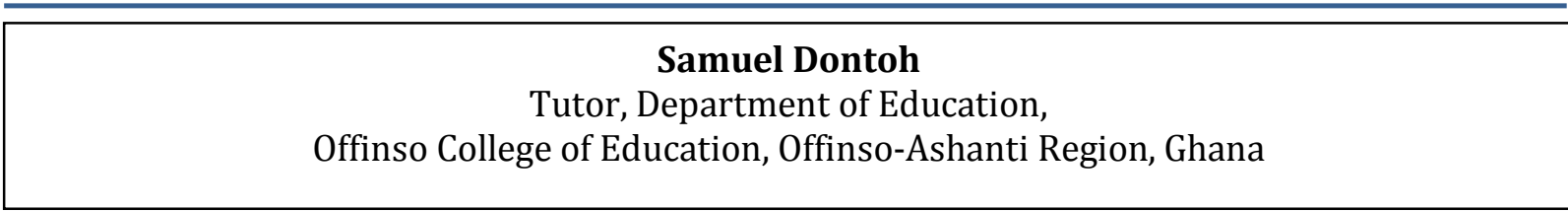

\begin{abstract}
:
Guidance and counselling play a very important role in the school system and the role of the school counsellor is seen as a central concern of stakeholders in senior high schools (SHS). However, little attention has been paid to the preconceived conceptions of the roles of the SHS counsellors held by students. In this article the researcher shares the results of an assessment of 400 public senior high school students' perceptions on the role of their counsellors in the Offinso Municipality. A descriptive survey design was used to collect data for this study. Stratified, purposive and simple random sampling techniques were employed in schools and students. A key finding was that, generally, students have positive perception on the role of the SHS counsellors. However, they considered the counsellors' role of assessment and appraisal as not so important. The study concluded that counsellors may be lacking the needed repertoire in the use of assessment and appraisal tool and that some positive action may be needed to urge counsellors to make use of test instruments and other forms of appraisals in ascertaining the needs of students for proper remediation. It was recommended that counsellor educators should be made aware of the perception SHS students hold concerning the counsellor's role on assessment and appraisal so as to enable him/her educate the counsellor trainees on their importance.
\end{abstract}

Keywords: Counselling, guidance, senior high school, students, role of counsellors

\section{Introduction}

In Ghana the need for guidance and counselling continues to feature prominently. Educationists and psychologists emphasize the need to include guidance and counselling in the educational programme. It has been realized that the choices students will have to make within a complex and a changing world due to advances in science and technology and the competitive market make it so crucial to provide senior high school students with the needed knowledge and skill to assist them think through issues and undoubtedly, these knowledge and skills could best be provided through guidance and counselling.

Guidance and Counselling in Ghana, until recently, seemed not to have attracted much attention by way of intense structural and curriculum reform. According to Essuman (1999) serious work in establishing guidance and counselling in schools, however, began in the late 1960s by the Curriculum Research Development Unit (CRDU) of the Ghana Education Service (GES). The institutionalization of guidance and counselling was informed by public outcry based on the need for change in the educational system. This culminated to the introduction of vocational counselling (Ackummey, 2003).

\subsection{The Need for Counselling in the Senior High Schools}

The world is increasingly becoming diverse with the development of technologies and expanding opportunities. To ensure that SHS students are prepared to become the next generation of parents, teachers, leaders, every student needs support, guidance and opportunities during adolescence because this period of life is characterized by rapid growth and change. SHS students face unique and diverse challenges both personally and developmentally, that impact on their academic achievement. Guidance and counselling in SHS are to enhance the learning process and to promote academic achievements. It is also essential for students to achieve optimal personal growth, acquire positive skills and values, set appropriate goals and realize full academic potentials to become productive, contributing members of the world community (American School Counsellor Association [ASCA], 2012).

Nziramasanga (1999) states that because of many pressures imposed on the family, parents tend to have little time for their children to give them the necessary guidance. The parents expect the school to provide solutions to the indiscipline in secondary schools caused by their children. UNESCO (2002:2) adds that "African adults have become more concerned with earning money and are less occupied with many traditional practices that formerly contributed to the upbringing of young people". 
ASCA (2012) is of the view that SHS counsellors are professional educators with a mental perspective and understand and respond to the challenges presented by today's diverse student population. Secondary schools' counsellors therefore do not work in isolation; rather they are integral to the total educational programme. They provide proactive leadership that engages all stakeholders in the delivery of programmes and services to help the students achieve success in the school. School counsellors align and work with the school's mission to support the academic achievement of all students as they prepare for the ever-changing world of the $21^{\text {st }}$ century.

This mission will be accomplished through the design, development, implementation of a comprehensive, developmental and systematic school counselling programme such as: individual student planning, student's appraisal, system support and collaboration with parents, teachers and administrators. To achieve this feat in SHS, the Ministry of Education (MOE) in a policy statement in 2007, mandated all second cycle schools to have school counsellors/guidance coordinators for the effective implementation of the guidance and counselling programmes.

\subsection{Perceptions of Students on Counsellors' Roles}

Over the past decades compelling evidence has shown that students' perceptions of their school counsellor have changed minimally. From the researches that exist, students often view their counsellors more in an administrative role (West, Kayser, Overton \& Saltmarsh, 1991). The researchers also concluded that on some occasion's students have perceived their counsellors as the primary source of assistance when discipline issues exist. With this situation existing in our schools, it is more likely students may seek help in administrative situation and or when disciplinary issues exist rather than for academic, vocational or for personal-social issues.

Nelson, Nazario and Andreoli-Mathie (1996), analysed data from a study with undergraduate students to determine students' perception of their counsellors based on the gender of the counsellor and the nature of the issue presented. The authors alluded to the fact that, although some students viewed school counsellors as specialists in many areas, personal issues are often not viewed as appropriate topics for discussions. This view presented by the students is quite disturbing and it needs to be looked at. Some possible questions that readily come to mind is whether students trust their counsellors, how they view them as a person, how do they perceive their roles?

Tennyson, Miller, Skovholt and Williams (1989) did a similar study with Minnesota secondary school counsellors. From the study it was concluded that on the whole, students' responses to the role of their counsellors was positive which is a good sign for counsellors. Also, Salami's (1989) study on attitudes towards counselling using two hundred and eighty students from College of Education, Oro, Nigeria, came out that students surveyed had positive attitudes towards counselling.

A startling revelation is Essuman's research (cited by Unachukwu \& Igborbor, 1991 p.337) about the problem of narrow perception of the roles and functions of the counsellor held by many Nigerians. Such a narrow perception drastically reduces the chances of having a good number of secondary school students seeking counsel because they do not perceive it as capable of solving their problems. What's more, Ackom (1992), using one hundred and eighty-two (182) students from the Western Region of Ghana, studied secondary school students' perceptions of the guidance coordinators roles in senior high schools. The study revealed that the students had what he described as 'low perception' of the guidance coordinator's roles and this he attributed to the fact that students did not feel much of the coordinator's impact. This attitude of the students could probably be attributed to the fact that generally students' perception of counsellor was negative and that students sought help from other individuals such as their peers.

In guidance and counselling, perception plays important role; it helps the counsellor to be in the internal frame of reference of the client. The assumption may be that, if a student views the roles of the counsellor in a positive light the probability that the student will access the services of the counsellor will be very high and vice- versa. All things being equal, one can assume that the specified roles may be carried out in the SHS as mandated by the MOE, but how students view these roles of the counsellor is another subject of equal importance as the performance of the roles of the counsellor. Against this background, this current study, therefore, seeks to examine the perceptions senior high school students hold regarding the counsellors' role in their respect school. The following research questions guided the study in pursuance of the purpose of the study:

- What is the most prevailing perception of SHS students on the role of the SHS counsellors in the Offinso Municipality?

- What gender differences exist between SHS student's perception on the roles of their counsellors in the Offinso Municipality?

\section{Methodology}

A descriptive survey design was used to collect data for this study. Osuala (2001) notes that descriptive surveys are versatile and practical especially to the researcher, in that they identify present needs. He further noted that descriptive research is basic for all types of research in assessing ongoing situation as a prerequisite for conclusions and generalization. This study fits into Osuala's (2001) description because the study seeks to find the current status of students' perception of their counsellors hence the descriptive survey.

The accessible population was made up of all the 2781 public SHS2 and 3 students in the Offinso Municipality in the Ashanti Region of Ghana. Offinso was chosen because of its cosmopolitan nature. Data for the study came from 400 students purposively selected through stratification. SHS 2 were chosen because it was supposed they have experienced life on campus for a year and so they might have experienced some form of counselling. SHS 3 students on the other hand were chosen because they were at the terminal point of one level of the educational ladder and some may enter the world 
of work. So, they were in a better position to tell whether or not they benefitted from the counsellor. For these reasons, their perceptions of the role of the counsellor would be fairly pronounced. Based on the school's enrolment, each of the schools was given a quota. In using the quota sampling technique, the researcher found the percentage of each group (i.e. boys and girls) in the total school population and the proportional sampling technique was used to determine each group's proportion in the sample. In all, four hundred (400) public SHS students made up of one hundred and forty-four (144) girls and two hundred and fifty-six (256) boys were used for the study

The instrument used in the study was the questionnaire. It consisted of two parts. Section A consisted of data on the demographic characteristics of respondents. Section B was made up of 30 items that elicited information from students on the counsellors' roles in the SHS. These scales comprised: (1) individual and group counselling, (2) developmental, educational and career guidance, (3) (assessment and appraisal, (4) consultation, referral and orientation, (5) coordination and management of a developmental and comprehensive programme and (6) professional ethics, personal growth and development. The sections were measured on a 5-point Likert scale. The gradation provided were: $1=$ not at all important, $2=$ not important, $3=$ somewhat important, $4=$ important, $5=$ very important.

The questionnaire was pilot-tested using Nkenkaasu Senior High School. After the analysis, some items were changed because students gave varied answers which showed that the questions were ambiguous; those questions were rewritten to elicit the needed responses. The scale however, had a Cronbach alpha reliability coefficient of 0.913

The collated data were statistically analysed with the aid of the SPSS version 20. Descriptive statistics (frequency distributions as well as means and standard deviations) were used to answer the research question one whiles the inferential statistics (An Independent t-test) was used to test the study's hypothesis (as stated in research question 2).

\section{Results and Discussions}

\subsection{Bio- Data Analysis}

The study sought to ascertain the gender differences of the students. As found in Table 1 the gender distribution of the data collected indicated male students constituted $64 \%$ and $36 \%$ for females. This shows that majority of the respondents were male. This probably suggests that in the SHS male students outweigh that of the females. The distribution is shown in Table 1.

\begin{tabular}{|c|c|c|}
\hline Gender & Frequency & Percentage \\
\hline Male & 256 & 64 \\
\hline Female & 144 & 36 \\
\hline Total & 400 & 100 \\
\hline
\end{tabular}

Table 1: Gender Distribution of Respondents

Source: Field Data (2020)

\subsection{Analysis of Research Questions}

- $\quad$ Research Question 1: What is the most prevailing perception of SHS students on the role of the SHS counsellors in the Offinso Municipality?

Respondents' perceptions on the various roles of their counsellors are presented in Table 2. The data collected using the questionnaire were analyzed using mean and standard deviation and tabulated as shown in Table 2. The following cut-off-point was used (1-1.5= not at all important, 1.5-2.5=not important, 2.5-3.5 = somewhat important, 3.5-4.5 = important and 4.5-5 = very important. The literature showed that, senior high school students often held different views about the roles of their counsellors and against this background, students were asked to indicate the extent of importance of how they viewed the counsellor's role.

\begin{tabular}{|c|c|c|c|}
\hline Scales & Counsellors Roles & Mean & SD \\
\hline 1 & Individual and Group Counselling & 4.27 & .534 \\
\hline 2 & Developmental Educational and Career Guidance & 4.11 & .674 \\
\hline 3 & Assessment and Appraisal & 3.42 & .928 \\
\hline 4 & Consultation, Referral and Orientation & 4.17 & .679 \\
\hline 5 & $\begin{array}{c}\text { Co-ordination and Management of a developmental and } \\
\text { comprehensive programmes. }\end{array}$ & \multirow{2}{*}{.642} \\
\hline 6 & Professional ethics, personal growth and development & 4.30 & .647 \\
\hline & Overall Perception & 4.04 & .487 \\
\hline
\end{tabular}

Table 2: Students' Perceptions of the Roles of the Counsellor

Source: Field data (2020)

The results from the field data as presented in Table 2 shows that students generally had a positive perception of the roles that counsellors perform in their schools. The students' overall mean score of their perception of the role of the counsellor was 4.04 and a standard deviation of 0.49 . Specifically, students' perception on professional ethics, personal growth and development had the highest mean of 4.30 and standard deviation of .647. The least in mean score of perception was the counsellor's role of assessment and appraisal, with a mean of 3.42 and standard deviation of .928. These results indicate that overall, students in the study viewed the role of the counsellor as important. For instance, 
under the scale 1, students perceived the counsellor's role of helping an individual student to resolve or remediate a problem such as drugs and interpersonal relationships as very important. Again, under scale 2, the students viewed the counsellors' role of conducting special programmes to meet the specific needs of students, for example, absenteeism, truancy and drug abuse as important. They also believed it was important for the SHS counsellor to provide students with educational and career information.

However, concerning scale 3, the students in the study generally perceived this role of the counsellor as somewhat important. With regards to specific item, the counsellors' role of interpreting and communicating assessment results to administrators, teachers, parents and guardians and the counsellor gathering information on all students who were having personal problems to make sure they get the help they needed were all viewed as somewhat important.

With the counsellor's role of scale 4, the respondents saw the following roles of the counsellor as important: the counsellor planning and providing orientation programme for new students to help them adjust to new school environment, the counsellor talking to parents or guardians about the needs and concerns of students and the counsellor talking with teachers about the needs or concerns of students. Under scale 6 , the student in the study believed it was important for the SHS counsellor to organize talks for students. Example, talks on careers.

The respondents also perceived the counsellor's role of making guidance and counselling goals and objectives for the good of the school and students as important. This finding is a good sign for counselling in the SHS in Ghana. However, this positive perception of the roles of the SHS counsellors as indicated by the students contradicts earlier findings that students placed the roles of the counsellor in a negative light (Unachukwu \& Igborgbor, 1991; Ackom, 1992; Ubana 2008). The differences in findings may be due to time elapse by the researchers and settings of the studies.

- Research Question 2: What gender differences exist between SHS student's perception on the roles of their counsellors in the Offinso Municipality?

An independent t-test to show the differences between the perceptions of male and female students on the role of SHS Counsellors was conducted and the results are indicated in Table 3.

\begin{tabular}{|c|c|c|c|c|c|c|c|}
\hline Scale: Counsellors roles & Gender & $\mathbf{N}$ & Mean & SD & $\mathbf{t}$ & Df & $\mathbf{p}$ \\
\hline $\begin{array}{l}\text { 1. Individual and } \\
\text { counselling }\end{array}$ & $\begin{array}{c}\text { Male } \\
\text { Female }\end{array}$ & $\begin{array}{l}256 \\
144\end{array}$ & $\begin{array}{l}4.26 \\
4.28\end{array}$ & $\begin{array}{l}.505 \\
.585\end{array}$ & -380 & 398 & .704 \\
\hline $\begin{array}{l}\text { 2. Developmental, Educational } \\
\text { and Career Guidance }\end{array}$ & $\begin{array}{c}\text { Male } \\
\text { Female }\end{array}$ & $\begin{array}{l}256 \\
144\end{array}$ & $\begin{array}{l}4.08 \\
4.17\end{array}$ & $\begin{array}{l}.934 \\
.913\end{array}$ & -1.364 & 398 & .173 \\
\hline 3. Assessment and appraisal & $\begin{array}{c}\text { Male } \\
\text { Female }\end{array}$ & $\begin{array}{l}256 \\
144\end{array}$ & $\begin{array}{l}3.41 \\
3.42\end{array}$ & $\begin{array}{l}.680 \\
.676\end{array}$ & -1.510 & 398 & .132 \\
\hline $\begin{array}{l}\text { 4. Consultation, Referral and } \\
\text { Orientation }\end{array}$ & $\begin{array}{c}\text { Male } \\
\text { Female }\end{array}$ & $\begin{array}{l}256 \\
144\end{array}$ & $\begin{array}{l}4.14 \\
4.23\end{array}$ & $\begin{array}{l}.639 \\
.641\end{array}$ & -1.177 & 398 & .240 \\
\hline $\begin{array}{l}\text { 5. Co-ordination and } \\
\text { management of developmental } \\
\text { programmes }\end{array}$ & $\begin{array}{c}\text { Male } \\
\text { Female }\end{array}$ & $\begin{array}{l}256 \\
144\end{array}$ & $\begin{array}{l}3.96 \\
4.08\end{array}$ & $\begin{array}{l}.639 \\
.641\end{array}$ & -11915 & 398 & .056 \\
\hline $\begin{array}{l}\text { 6. Professional ethics, personal } \\
\text { growth and Development }\end{array}$ & $\begin{array}{c}\text { Male } \\
\text { Female }\end{array}$ & $\begin{array}{l}256 \\
144\end{array}$ & $\begin{array}{l}4.25 \\
4.38\end{array}$ & $\begin{array}{l}.642 \\
.649\end{array}$ & -1.858 & 398 & .0 .64 \\
\hline
\end{tabular}

Table 3: An Independent T-Test of Students' Perception Based on Gender

Source: Field Data (2020)

From scales 1,2,4,5 and 6 the respondents, both males and females, have positive perceptions about the roles of the counsellor. However, the independent t-test conducted revealed that there was statistically no significant difference between males and females on their perception on the counsellor's roles even though female students seem to endorse the roles of the counsellor more than their male counterparts. (e.g. $\alpha=0.05 p=.24$ )

The result is not surprising in that naturally female students are good in interpersonal relationship, self-disclosure and openness than male students who are rigid and reserved in their relationships, hence cannot interact often with the guidance counsellors nor seek their services. It would therefore be unlikely for male students to rank the roles of counsellors highly because they do not 'consume' the services of the counsellor. This view is related to Van Der Riet and Knoetze's (2004) opinion that "male students are normally socialized to be strong and cope with their own problems" (p. 237). Most importantly, this finding is in agreement with Onyejiaku (1991) who asserted that despite sex differences, the attitude of males and females to some extent are favourable towards counselling services.

On the whole, the analysis of the responses showed that the respondents in the study had a positive perception on the roles of the SHS counsellors. All the roles specified were considered important except that of scale 3 on 'assessment and appraisal' where students perceived the role as somewhat important. The question that readily comes to mind is what is happening to this role of the counsellor? Is this role lacking in the senior high schools or counsellor trainees are not equipping the student-counsellors with adequate skills when it comes to the issue of assessment and appraisal? This issue is very worrisome because the responses from the students showed that probably this role of the counsellor was lacking in the SHS.

\section{Conclusion and Implications of the Findings for Counselling}

The general perception derived from the study suggested that five out of the six specified roles of the counsellor were perceived by the respondents as important. These roles include: individual and group counselling, developmental, educational and career guidance consultation, referral and orientation, co-ordination and management of a developmental 
and comprehensive programme, professional ethics and personal growth and development. Students' knowledge on the specified roles of the counsellor showed a positive perception about counselling and this is a good sign for the counselling profession in Ghana.

Senior High School Counsellors should therefore work towards maintaining this positive perception of the counselling profession. This positive perception is recommendable. This implies that there is awareness among students on the importance of the roles of the counsellor. Since students are aware of these roles, it is a good opportunity for the SHS counsellor to utilize this positive perception to intensify his or her services and to provide other services that may be lacking.

The findings however, showed that students perceived the counsellor's role of 'assessment and appraisal' generally as somewhat important. The possible explanation could be that, this role of the counsellor is lacking in the SHS and that there is limited training in this area for the student counsellor. Assessment and appraisal are important tools in counselling. It deals with gathering information which helps the SHS counsellor to assist students, but as seen from the research results, SHS counsellors seem to lack this skill; in this case the information gathered on students will be limited. Therefore, respondents' perception on the counsellors' role of assessment and appraisal need to be noted in the training of counsellors.

\section{Recommendations}

The following recommendations were made:

- The counsellor educators or trainers should include in their counsellor training course an aspect on assessment and appraisal skills so that counsellor-trainees will have the skill to perform these roles.

- In addition, the perceptions of SHS students on the counsellor's role of assessment and appraisal need to be corrected. To do away with this erroneous impression, the heads of institutions may need to make sure that counsellors they appoint in the schools have adequate training to handle the guidance and counselling programme. GES should also join forces in planning and implementing the curriculum for school counsellor training.

\section{References}

i. Ackom, P.E. (1992). Secondary school students' perception of guidance co-ordinators: A study in the Western Region of Ghana: University of Cape Coast. Unpublished M. Ed Thesis.

ii. Ackummey, M. A. (2003). Organization and administration of a school guidance programme. Accra: Media Graphics \& Press Limited

iii. American School Counsellor Association (2012). Roles of the school counsellor. Retrieved $18^{\text {th }}$ august 2020 from Error! Hyperlink reference not valid..

iv. Essuman, J. K. (1999). The history of guidance and counselling in Ghana. Ife Psychologia. An International Magazine. Vol. 7(2) 22-43.

v. Ghana Education Service (1976). Establishment of guidance and counselling programmes in second cycle institutions. DG/040/9A.

vi. Ministry of Education (2007). Government policy on guidance and counselling in schools, Retrieved on $12^{\text {th }}$ August, 2020 from http://www.ghana.gov.gh/index.php/governance/ ministries/331-ministry-of-education

vii. Nelson, E. S., Nazario, E. R., \& Andreoli-Mathie, V. (1996). Attitudes toward the counsellor as related to counsellor gender, the type of presenting problem, and attitudes toward women. Virginia Counsellors Journal, $24,50-66$.

viii. Nziramasanga C.T. (1999). Report of the presidential commission of Inquiry into the education and training. Harare: Government Printers.

ix. Onyejiaku, F. O. (1991). Psychology of adolescent: Nigeria: Calabar: Rapid Publishers, Ltd.

x. Osuala, E.C.(2001). Introduction to research methodology (2nd ed.) Onitsha, Nigeria: EEP Publishers Ltd.

xi. Salami, S.O. (1998). Attitudes towards counselling among rural college students in Nigeria. Ife Psychologia: An International Journal 6(2) 116- 128.

xii. Tennyson, W.W., Miller, G. D., Skovholt, T. M. \& Williams, R. C. (1988). Secondary school counsellors: What do they do? What is important? The School Counsellor, 36, 253-259.

xiii. Ubana, A. N. (2008). Attitude of secondary school students' towards guidance and counselling services in Yakurr Local Government Area in Cross River State. An unpublished B.Ed Thesis, Cross River University of Technology, Calabar.

xiv. Unachukwu, G. C., \& Igborgbor, T. (1991). Guidance and counselling: A realistic approach. Nigeria: International Universities Press.

xv. UNESCO (2000a). Guidance (Module I). France: Agzi Communication.

xvi. UNESCO (2002, April, 22-26). Terms of reference: The first international conference on guidance and youth development in Africa, Kenya: Nairobi, 1-2

xvii. Van der Riet, M., \& Knoetze, J. (2004). Help seeking pattern in urban and rural youth in two South African Provinces: A socio-contextual view. School Psychology International, 25(2), 223-240.

xviii. West, J. S., Kayser, L., Overton, P., \& Saltmarsh, R. (1991). Student perceptions that inhibit initiation of counselling. The School Counsellor, 39, 72-83. 